\title{
AEROMAGNETIC MAP OF THE WILLIMANTIC QUADRANGLE AND PARTS OF THE SPRING HILL AND SCOTLAND QUADRANGLES, NEW LONDON, WINDHAM, AND TOLLAND COUNTIES, CONNECTICUT
}

GEOPHYSICAL INVESTIGATIONS

MAP GP- 851 